\title{
Bioinformatic analysis of the CLE signaling peptide family Karsten Oelkers' ${ }^{1,4}$, Nicolas Goffard ${ }^{2,4}$, Georg F Weiller ${ }^{2,4}$, Peter M Gresshoff 3,4 , Ulrike Mathesius*1,4 and Tancred Frickey ${ }^{2,4}$
}

\author{
Address: ${ }^{1}$ School of Biochemistry and Molecular Biology, The Australian National University, Canberra, ACT, Australia, ${ }^{2}$ Research School of \\ Biological Sciences, The Australian National University, Canberra, ACT, Australia, ${ }^{3}$ The University of Queensland, Brisbane, QLD, Australia and \\ ${ }^{4}$ The Australian Research Council Centre of Excellence for Integrative Legume Research, The University of Queensland, Brisbane, QLD, Australia \\ Email: Karsten Oelkers - karsten.oelkers@anu.edu.au; Nicolas Goffard - nicolas.goffard@anu.edu.au; \\ Georg F Weiller - georg.weiller@rsbs.anu.edu.au; Peter M Gresshoff - p.gresshoff@uq.edu.au; Ulrike Mathesius* - ulrike.mathesius@anu.edu.au; \\ Tancred Frickey - tancred.frickey@anu.edu.au \\ * Corresponding author
}

Published: 9 February 2009

BMC Plant Biology 2009, 9:17 doi:10.1 |86/147|-2229-9-17
Received: 2 February 2009

Accepted: 9 February 2009

This article is available from: http://www.biomedcentral.com/I47/-2229/9/17

(C) 2009 Oelkers et al; licensee BioMed Central Ltd.

This is an Open Access article distributed under the terms of the Creative Commons Attribution License (http://creativecommons.org/licenses/by/2.0), which permits unrestricted use, distribution, and reproduction in any medium, provided the original work is properly cited.

\section{Correction}

After the publication of this work [1] we became aware of the fact that in Supplementary File 2 some of the sequence identifiers (i.e. CLE numbers) of the Medicago truncatula CLE protein sequences in the multiple alignments were incorrect. Table 1 shows the corrected CLE numbers. Additional file 1 and Additional file 2 show a full corrected list of all CLE peptides with their corresponding groupings. The tables within these files also include iden-

Table I: Corrected CLE numbers for Medicago truncatula CLE peptides

\begin{tabular}{llll}
\hline Suppl.2 & Corrected & Corrected & Suppl.2 \\
CLE35 & CLE7I & CLE35 & CLE69 \\
CLE36 & CLE74 & CLE36 & CLE66 \\
CLE37 & CLE39 & CLE37 & CLE74 \\
CLE38 & CLE65 & CLE38 & CLE7I \\
CLE39 & CLE70 & CLE39 & CLE37 \\
CLE64 & CLE67 & CLE64 & CLE65 \\
CLE65 & CLE64 & CLE65 & CLE38 \\
CLE66 & CLE36 & CLE66 & CLE72 \\
CLE67 & CLE69 & CLE67 & CLE64 \\
CLE69 & CLE35 & CLE69 & CLE67 \\
CLE70 & CLE73 & CLE70 & CLE39 \\
CLE7I & CLE38 & CLE7I & CLE35 \\
CLE72 & CLE66 & CLE72 & CLE73 \\
CLE73 & CLE72 & CLE73 & CLE70 \\
CLE74 & CLE37 & CLE74 & CLE36
\end{tabular}

The table shows the CLE numbers in the original Supplement 2, and the corresponding corrected numbers. tifiers for those sequences that were not grouped in Figure 2 of the original article [1].

We regret any inconvenience that this inaccuracy in the data might have caused.

\section{Additional material}

\section{Additional file 1}

Full listing of CLE peptide numbers for each group of CLE peptides, sorted by CLE peptide number. Table: The groups correspond to those shown in Figures 2 and 3 of the original article [1].

Click here for file

[http://www.biomedcentral.com/content/supplementary/14712229-9-17-S1.doc]

\section{Additional file 2}

Full listing of CLE peptide numbers for each group of CLE peptides, sorted by CLE peptide groups. Table: The groups correspond to those shown in Figures 2 and 3 of the original article [1].

Click here for file

[http://www.biomedcentral.com/content/supplementary/14712229-9-17-S2.doc]

\section{References}

I. Oelkers K, Goffard N, Weiller GF, Gresshoff PM, Mathesius U, Frickey $\mathrm{T}$ : Bioinformatic analysis of the CLE signaling peptide family. BMC Plant Biol 2008, 8: I. 